Meyrbaev B.B., Badagulova Zh.

The introduction to the Docetism Controversy

Мейрбаев Б.Б., Бадагулова Ж.

Аокетизм полекимикасына кіріспе

Мейрбаев Б.Б., Бадагулова Ж.

Введение в полемику докетизма
To control the masses, the political organization of the church declared that salvation can only be achieved through religious rituals and priesthood. Salvation through the personal mystical experience with Christ outside the organized church has been thrown out. Christian Gnosticism was obliterated and relatively little historical and theological information was left to fully understand early Christian history. Docetism as one of the earliest Christian Gnostic movements eventually was eradicated from Christian history. According to the historians Docetic Gnostic wrote his own Gospel including The Acts John and, as mentioned previously, The Gospel of Peter. But genuinely their attitude opposite the Church's main ideology concerning Jesus and his personality which leads to cruel excommunication of Docetism.

Key words: docetism, gnosticsm, heresy, Gospel, Christology, New Testament, Christology, The Gospel of Peter.

Бұқара халықты басқару үшін, шіркеу құтқарылуға Аіни ғұрыптар мен қасиеттілік арқылы жетуге болатынын ресми түрде мәлімдеді. Шіркеуден тыс жүретін Христостық мистикалық тәжірибе арқымы құтқарылу қабылданбайды деп жарияланды. Осылан соң христиандық гностицизм жойылды. Осы себепке байланысты докетизмнің маңызды аспектілерін ашуға қауқарлы тарихи және теологиялық дереккөздер салыстырмалы түрде аз болды. Аокетизм ерте христиандық гностикалық ағымдардың бірі болды және де ең ақырында ол ағым шіркеуден аластатылып, ересь деп жарияланды. Тарихшылардың пікірінше, докетизмді ұстанушылардың өз Евангелиесі болған және оның құрамында Иоанның ашылулары, Петрдің Евангемиясының үзінділері қамтылған. Бірақ басты мәселе ретінде Иисус пен оның тұлғасын түсіндірудегі қарама-қайшылықтар алға шықты және де олар докетизм ізбасарларын анафемаға тартуға алып келді.

Түйін сөздер: Аокетизм, гностицизм, ересь, Евангелие, христология, Жаңа Өсиет, Петрдің Евангелиесі.

С целью управлять массами церковь официально заявила, что спасения можно Аостигнуть Аишь посреАством религиозных обрядов и священств. Спасение вне церкви через мистический опыт в Христе был объявлен неприемлимым. Христианский гностицизм впос^еАствие бы^ уничтожен. По этой причине оста^ось сравнительно мало исторических и богословных источников, которые могли бы раскрыть важные аспекты проблемы докетизма. Аокетизм, являясь оАним из самых ранних христианских гностических Авижений, в конечном счете был отлучен от цекрви и объявлен ересью. По мнение историков у последователей докетизма было собственное Евангелие, которое вк^ючало некоторые отрывки откровения Иоанна и отрывки Евангелия от Петра. Но центральной проблемой все же остается противоречие в интерпретации Иисуса и его мичности, которое и приве^о к преданию анафеме последователей докетизма.

Ключевые слова: докетизм, гностицизм, ересь, Евангелие, христология, Новый Завет, Евангелие от Петра. 


\section{THE INTRODUCTION TO THE DOCETISM CONTROVERSY}

\section{The place of Docetism in Gnosticsm}

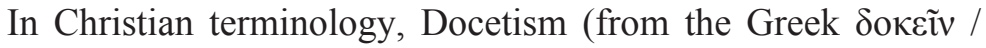

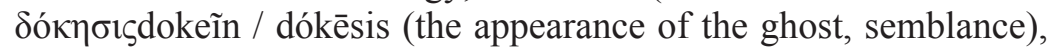
is the belief that Jesus Christ was not a real person, but simply appeared as one. It undermines not only Incarnation but Redemption and Resurrection of Jesus. Geisler linked to Bettenson's explanation of docetism as «the assertion that Christ's human body was a phantasm, and that his suffering and death were mere appearances. 'If he suffered he was not God; if he was God he did not suffer'» [1, p. 370]. Actually the main issue in the understanding of Docetism controversy is the lack of profound and authoritative resources. Since the real knowledge about Docetism has been long-lost, there are no solid proofs of genuine context of Docetism in today's revising of the Gospels and singling out the facts. Hereinafter article seeks to precise information about the conflicts which led to eradication of Docetism in the history of Christian Church.

Docetism origins are not Biblical, but Hellenistic and oriental. Docetism is associated with the idea that matter is essentially evil and the specific construction of the doctrine of divine disinterest. Those days Alexandria was a melting pot of Hellenistic and Oriental ideas, and home to some of the great Gnostic teachers. It is not surprising that there was a tendency to the docetic views even in some «orthodox» writers as Clement and Origen. Zealous attempts of Church to hide any links and refferences to the Gnostic roots, nevertheless, are revealed. Clement of Alexandria also knew of a group known as Docetists without explaining what they believed; he simply observes that their name derives from their doctrine (early third century; StromateisVII.xvii). Clement did opine that the founder of Docetism was Julius Cassian. In Elucidations, Clement of Alexandria explicated that the doctrine of Christ Jesus only appeared human, namely «docetism of Cassian, who had presumed to speak of the body of Jesus as a phantasm», is destructive to the Christ of the Gospel. [2, p. 263-264].

Docetism is not actually Christian heresy because it does not arise in the church misunderstanding of a dogma. The enmity between spirit and matter is the main Gnostics' principle. It makes all salvation to become free from the bondage of matter and the return 
to the pure spirit of the Supreme Spirit that could not accept the phrase «the Word was made flesh» in the factual sense. They were strained to change the doctrine of the Incarnation by borrowing ideas from the Christian doctrine of the Savior who was the Son of God. Their embarrassment with this dogma engendered many inconsistencies, some of the innates of Aeon in the body, which was a real body or humanity in general, others deny the real objective existence of any humanity in general, other allowing a «psychic» but not a «holyc» existence of real body, and others are likely to accept the body but not the reality of Jesus being born by a woman, or the reality of suffering and death on the cross. Christ seemed to suffer either because he ingeniously and miraculously substituted someone else to endure the pain, or because the appearance of Calvary was an optical illusion. Simon Magus is the first who offered explanations to Docetism»putative passion of Christ and blasphemously asserted that it was really his, Simon himself, who underwent these apparent sufferings» [3, p. 121]. As the angels governed this world badly because each angel coveted the principality for himself he came to improve matters, and was transfigured and rendered like onto the Virtues and Powers and Angels, so that he appeared amongst men as man though he was no man and was believed to have suffered in Judea though he had not suffered» (passum in Judea putatum cum non esset passus - Irenaeus, Adv. Haer. I, xxiii sqq.) [4, p. 34]. The mention of the demiurgic angels marks this passage as a piece of Gnosticism.

In the face of this display Docetism, Michael Slusser suggests that «Docetism» be defined in conformity with the broad historical use of the term («the human appearance of Christ is mere illusion and has no objective reality» [5, p. 258-259]), though he cautions that the word «appearance» should be construed as referring to Christ's whole earthly career, rather than to his countenance or the mode of his arrival [6, p. 163-172]. Norbert Brox concerned differentiate old Docetism from modern Christological problems suggests that the term «Docetism» is used to mean that the doctrine consciously distinguished manifestation of Jesus his essence: «Docetism lies at hand where a christology claims: Jesus was different from what he seemed to be» [7, p. 301-314]. These two definitions strain to accommodate different data they process, but it is unlikely that any single definition of Docetism satisfies many conflicting accounts of what was the old Docetism. While Brox more consciously distinguished former Docetism related to modern phenomena, he and Slusser offered definitions which, if followed strictly, provide use- ful clarity to the discussion of this elusive subject. Docetic Gnostic wrote his own Gospel including The Acts John and, as mentioned previously, The Gospel of Peter. The Gospel of Peter quotes Justin Martyr, Origen, Eusebius, but was not detected until 1886 researchers.

Docetism essentially Christology strongly influenced by Greek basic assumptions of both varieties of Plato and Aristotle. Plato taught the idea of the gradation reality. The spirit, or mind, or thought is the highest, according to his ultimate philosophy. The material is less real. This distinction grades ontological reality that it probably ethically deteriorates the people. Thus, the matter came to be thought of as morally bad [8, p. 133].

Mühlenbergclaim that the earliest reference to the concept of docetism is found in the letters of Ignatius of Antioch to the churches of Asia Minor. He explained that these epistles Ignatius warned the churches «to beware of false teachers who maintain that Jesus Christ «only appeared to suffer» and thus to undergo birth, eating and drinking, persecution and crucifixion under Pontius Pilate, and resurrection in appearance only.» [9, p. 21]. Arendzen, J. claims that the earliest docetism had to disappear due to specific reasons. The earlier Docetism seemed destined to die with the death of Gnosticism when it received a long lease of life as parasitic error to another heresy, that of Manichaeism. Manichaean Gnostics started with a two-fold eternal principle, good (spirit) and evil (matter). In order to add Christian soteriology to Iranian dualism, they were forced, as the Gnostics were, to tamper with the truth of theIncarnation. Manichees distinguished between a Jesus patibilis and a Jesus impatibilis or Christ. The latter was the light as dwelling in, symbolized by, or personified under, the name of the Sun; the former was the light as imprisoned in matter and darkness; of which light each human soul was a spark. Jesus patibilis was therefore but a sign of the speech, an abstraction of the Good, the pure light above. In the reign of Tiberius Christ appears in Judea, Son of the Eternal Light and also Son of Man; but in the latter expression «man» is a technical Manichaean term for the Logos or World-Soul; both anthropos and pneuma are emanations of the Deity. Though Christ is son of man He has only a seeming body, and only seemingly suffers, His passion being called mystical fiction of the cross. It is obvious that this doctrine borrowed from that of the Incarnation nothing but a few names. Scattered instances of Docetism are found as far West as Spain among the Priscillianists of the fourth and the fifth century. The Paulicians in Armenia and the Selicians in Constantinople fos- 
tered these errors. The Paulicians existed even in the tenth century, denying the reality of Christ's birth and appealing to Luke 7:20. God, according to them, sent an angel to undergo the passion. Hence, they worshipped not the cross but the Gospel, Christ's word. Among the Slavs the Bogomilae renewed the ancient fancy that Jesus entered Mary's body by the right ear, and received from her but an apparent body. In the West a council of Orléans in 1022 condemned thirteen Catharist heretics for denying the reality of Christ's life and death. In modern theosophic and spiritist circles this early heresy is being renewed by ideas scarcely less fantastic than the wildest vagaries of old [2, p. 45].

Ardzen argued that the basic ideas about Jesus existed much longer through assimilation with the principles of Manichaean and some Slavs tribes. There was a widespread situation when Jesus is personificated instead of the Sun or other local God, whose worshipping started to take forms of monotheistic tendency.

Gnosticism was heavily attacked historical Christianity or attempted penetration or subverted it. Gnostics linked to most of the works that have come into their New Testament and was written in contrast with them, or in order to distort them. To encourage Christians to take their books, the Gnostics, that the books were written by the apostles or other famous characters of the Gospels and Acts. Otherwise, the New Testament has been forged. A prominent scientist of any kind does not accept any of the names of their authors.

Peter Jones says that Docetism held deep knowledge, and their scholars are close to the logical and rational perception of the outer world, «Gnosticism is formed from the Greek term gnosis meaning knowledge, but it means here a particular form of knowledge, namely 'spiritual experience.»" Like all pagan spirituality, so-called 'Christian' Gnosticism engages in 'sacred technologies' (occult meditations, chanting mantras, drumming, etc.) to access the higher, spiritual self, and the self that is part of God. In this essential out-of-body experience, all physical and this-worldly restraints, like rational thinking and a sense of specific gender, fall away. In a word, the experience of 'enlightenment' is both the rejection of the goodness of the physical creation and an acquisition of the knowledge of the divinity of the human soul» [10, p. 21].

By this Peter Jones argued that it is impossible to determine the original source of occurrence Docetism. There are assumptions that it borrows from Platonism, the Egyptian religion, the cults of the Greek mysteries of Zoroastrianism, Kabbalah,
Judaism, and probably Buddhism. Regardless, there were the beginnings of it, even in the first century, and we can find the seeds even in the New Testament that some of the New Testament writers are beginning to try to fight against Gnosticism.

Gnostics claimed Christians one step below them in the scale of enlightenment, Jesus gave a secret knowledge that should not be accessible to the uninitiated. As an example, the Gospel of Judas claims Jesus gave secret instructions to Judas, who was the most enlightened disciple. As the Gospel of Judas is a Gnostic class took devilish delight standing Christian teaching on their head and make up stories to discredit God the Father, Son and Holy Spirit - the equivalent of a modern artist puts an end (crucifix) to the bottle of urine.

\section{The Gospels and Docetism}

Docetism is mentioned in the Gospels but mostly specified in the Gospel of Peter and John. The following focuses on the opinions of scientists about the role and influence of the Gospel on the importance of Docetism. In the last days of 1945, the early Christian texts that contain many mysteries of the Christian religion were found in Upper Egypt, supposedly a place where many Christians fled during the Roman invasion of Jerusalem. As they were covered nearly two thousand years ago, these manuscripts of Christian mysticism are magnitude to the Dead Sea Scrolls. These works confirmed the existence of the doctrine of reincarnation taught one of the first Jews and Christians. These Christian mystics called Gnostic Christians were eventually destroyed by the Orthodox Church as heretics. Their scriptures were destroyed, hidden in the belief they would be revealed at the appropriate time in the future. The discovery in 1945 led to the works, which included some lost gospels, some of which were written before the Gospels known to Matthew, Mark, Luke and John. Brian A. Bain has this to say about the 1945 discovery, «Long considered to be heretical, ancient Gnostic Christian texts unearthed this century display compelling similarities between Gnostic conceptions of life and death and modern near-death experiences. The Gnostic texts devoted extensive tracts to what readers could expect to encounter when they died. Other passages make numerous allusions to near-death-like experiences that can be realized in this life, most notably the human encounter with a divine light. The Gnostic Christian literature gives us one more example of NDEs and similar experiences in the ancient world» $[11$, p. 85]. 
So it leads to the next comparison of the Gospels. The list of agreements between the two gospels against other Gospel texts is an impressive and requires explanation. The Gospel of Peter always stamp Docetic; This view has been challenged by recent studies. Even if we accepted that as the Gospel of Peter and the Acts of John under the influence of Docetism, this is unlikely to explain a number of agreements. Christ's head reaching to (or beyond) heaven as well as the verbatim agreements of 'pierce', 'reed', 'gall' and 'vinegar' is difficult to connect with docetic Christology; also, whereas 'taken up' in the Acts of John reflects a Docetic concept (Christ did not suffer), the Gospel of Peter follows the sequence of death, burial, and resurrection [12, p.251].

The account of the resurrection in The Gospel of Peter is also Docetic. Tomas Nelson appeal to the real situation which occurred to Jesus, while he was crucified, "And in the night in which the Lord's day was drawing on, as the soldiers kept guard two by two in a watch, there was a great voice in the heaven; and they saw the heavens opened, and two men descend from thence with great light and approach the tomb. And that stone which was put at the door rolled of itself and made way in part; and the tomb was opened, and both the young men entered in. When, therefore those soldiers saw it, they awakened the centurion and the elders; for they too were hard by keeping guard. And as they declared what things they had seen, again they see three men come forth from the tomb, and two of them supporting one, and a cross following them: and of the two the head reached unto the heaven, but the head of him who was led by them overpassed the heavens. And they heard a voice from the heavens saying, Thou had preached to them that sleep. And a response was heard from the cross, Yea. (Gospel of Peter, verses 9-10). Of the new features in this fragment some are at least liable to a Docetic interpretation, e.g., the silence on the cross «as though he had no pain» (sec. 4), the cry, «My power, my power» (sec. 5), and «he was taken up» (sec. 5). This fact was recognised in subsequent times and condemned this gospel in the eye of the church [13, p. 211].

Tomas Nelson noted, too, there is no actual date of this event. Different scholars give certain dates when crucifixion might have happened. While Ron Cameron argues that the Gospel of Peter is independent of the canonical four (The Other Gospels, pp. 77-8). But as it was mentioned above Gospel of Peter could not be taken as Scripture of witness cause identification of the sources of the Gospel of Peter is a matter of considerable debate.
However, the language used to portray the passion provides a clue to the use of sources, the character of the tradition, and the date of composition. Analysis reveals that the passion narrative of the Gospel of Peter has been composed on the basis of references to the Jewish scriptures. The Gospel of Peter thus stands squarely in the tradition of exegetical interpretation of the Bible. Its sources of the passion narrative are oral tradition, understood in the light of scripture, interpreted within the wisdom movement. This accords with what we know of the confessions of the earliest believers in Jesus: in the beginning, belief in the suffering, death, burial, and resurrection of Jesus was simply the conviction that all this took place «according to the scriptures» (I Cor. 15:3-5). In utilizing scriptural references to compose the work, the Gospel of Peter shows no knowledge of the special material distinctive to each of the four gospels now in the New Testament. The developed apologetic technique typical of the Gospel of Matthew and of Justin (a church writer who lived in the middle of the second century), which seeks to demonstrate a correspondence between so-called prophetic «predictions» in the scriptures and their «fulfilments» in the fate of Jesus, is lacking. The use of quotation formulas to introduce scriptural citations is also absent [14, p. 77-82].

All of this suggests that the Gospel of Peter is an independent witness to the evangelical tradition. Early composition would be in the middle of the first century, when the stories of passion began to compile.

Kester has doubted this hypothesis for several reasons: The Gospel of Peter has been preserved in the manuscript are often late, making sure that the text is difficult; Crossan seems to underestimate the role of oral traditions and influences all the materials of the gospel of early non-canonical sources; Ultimately, the emergence of stories may not be present in the stories of passion, because they are independent from each other in the canonical Gospels. Kester reached somewhat different conclusions about the history of the passion behind Peter: "The Gospel of Peter, as a whole, is not dependent upon any of the canonical gospels. It is a composition which is analogous to the Gospels of Mark and John. All three writings, independently of each other, use an older passion narrative which is based upon an exegetical tradition that was still alive when these gospels were composed, and to which the Gospel of Matthew also had access. All five gospels under consideration, Mark, John, and Peter, as well as Matthew and Luke, concluded their gospels with narratives of the appearances of Jesus 
on the basis of different epiphany stories that were told in different contexts. However, fragments of the epiphany story of Jesus being raised from the tomb, which the Gospel of Peter has preserved in its entirety, were employed in different literary contexts in the Gospels of Mark and Matthew.» [15, p.240].

Although it is not commonly understood Gnostic John has elements in common with Gnosticism. Christian Gnosticism does not develop fully until the middle of the second century and the second century Christians concentrated a lot of effort to review and refute. To tell the Gospel of John contains elements of Gnosticism is the assumption that Gnosticism had developed to a level that requires the author to answer to it. The comparison to Gnosticism does not lie in the act that the author says, but in the language that he uses, including the ideas of Logos and Light. John was interpreted differently by Gnostics.Gnosticism taught that salvation came from gnosis, secret knowledge, and the Gnostics did not see Jesus as a Savior, but frankly knowledge. Some scholars argue that the Gospel teaches that salvation can only be achieved through the revealed wisdom, faith in Jesus especially. Rev. D.H. Stanton, in The Journal of Theological Studies did researches rely on works of Eusebius and Serapion of Antioch. According to the D.H. Stanton Apollo was connoted to Jesus in Gospel. Thus, the influence of Gnosticism cannot be denied: 'The conclusion with which we are confronted is that the Gospel of Peter once held a place in honour comparable to that assigned to the four Gospels, perhaps even higher than some of them'. This conclusion is supported by a reference of Justin Martyr (circa 160) to the Gospel then called Petra (Peter, today) but there is evidence in the Secret Vatican Archives that the writings attributed to Justin Martyr were written in the Fifth Century and retrospectively applied to him. Serapion of Antioch (c. 205) records that 'an odd writing called Petra' was in presbyterial use during his time but later, according to Eusebius (d. 339) it was 'withheld' because 'it contained some heresy'. That 'heresy' was the fact that Apollo was the god mentioned in that Gospel, not Jesus Christ, and the latter's name was written over Apollo's name in more modern times [16, p. 74].

To the Gnostics, the Gospel of John shows the clearest similarities to the later Gnostic writing style, and of the Gospels have the same quality of dreamlike style in the writing (Gospel of Truth). The phrase»and the Word became flesh, and dwelt amongst us» $[18$, p.165] as a rule, regarded to against Docetism, the belief that many of the Gnostics believed that Jesus' human nature was illusory, as inherent perfect Savior Christ could not participate in a corrupt nature (Gnosticism) the nature of the material. In addition, the first sentence is usually understood as anti-Arian, in the $4^{\text {th }}$ century Christian sect, later branded as a heretic, who said that there was a time before the advent of Jesus.

Therefore, John emphasizes the importance of an encounter with Jesus and his community against the pressures of pro-docetic tendencies. It is also in the late gospel material, comparison of Peter and the beloved disciple. Despite some claims, the Gospel of Peter is not in the New Testament, because it seriously changed. For these reasons, most scientists now reject the Gospel of Peter, to give us a portrait of Jesus as precise as the standard of the Gospel of the New Testament and consider this structure since the end of the second century.

\section{Conclusion}

In addition, to what has been revised, there are still certain problems remain unrevealed in Doceticsm. The central problem is concerning the decision of the Church to excommunicate Docetism. There are some reasonable motives as Gnosticism' refuses had been taught in the writing of the Old Testament. In their opposition to Gnosticism, the Church rulers turned to ancient writings, history, tradition and their own authority obviously appointed Christian leaders. These battles have helped to evolve the church. The three main results of the battle with Gnosticism have an increased emphasis on the apostolic succession, the tightening of the definition of the hierarchy of the church and the biblical canon. One way to counter the inventions of the Gnostics was to show that as the leader of the church you the truth, because you have been trained and commanded the man who was trained and commanded by a person who has been trained and supervised by the apostle, who was trained and controlled by the Christ and the Church developed the idea of apostolic succession. When there were only a few generations of church leaders, and the leader of the Church of Christ was separated, this argument finally took a considerable force.

Another way to confront heresy was to emphasize church leadership hierarchy in which no man can be a priest or a bishop if he did not stand in the tradition of previous leaders. This also happened. And finally, with books claiming the authority of the apostles or their associates, it became necessary to decide which were authoritative and which were not. The results would define the canon of Scriptures.There is one Lord - Christ Jesus - and just as he laid down his life 
for his friends, so should his followers be willing to do on behalf of others.So, staying away from idols becomes a leading measure of one's love for Christ and for one another. This being the case, the Elder's struggle was not against Gnostic perfectionists, who claimed to have «arrived» spiritually and were thus beyond reproach [18, p. 332]. Thus, non-suffering of Jesus means non-suffering of discipleship. Since Jesus did not suffer, his disciples should not suffer neither; worldly life has apologized for Docetic Christology.

To control the masses, the political organization of the church declared that salvation can only be achieved through religious rituals and priesthood. Salvation through the personal mystical experience with Christ outside the organized church has been thrown out. In a move that is likely to meet with the disapproval of Christ himself, the political aspirations of some of the priests of the world prevailed over the spiritual awakening of the majority. And, as a religion or movement, the heirs of the founder, who decided to keep and throw things. The church rejected the spiritual knowledge of Christian Gnosticism being too dangerous and kept the concept of blind acceptance of church doctrine.

Christ's entity, then abandoned Jesus on the cross. Docetism was rejected determinedly at the first Council of Nicaea in 325 AD. Docetism largely disappeared during the first millennium. For the most of the church, four Ecumenical Councils of Nicaea, Constantinople, Ephesus, Chalcedon are to clarify and define the nature of man and the divine nature of Jesus Christ.

Finally, The church declared Christian Gnosticism as heresy and began to kill those who adhered to its doctrines. Thus, the powerful Roman Church began its crusade of eliminating all rivals to its authority. Christian Gnosticism was obliterated and relatively little historical and theological information was left to fully understand early Christian history. This all changed in 1945 with the discovery of the Gnostic Christian scriptures discovered in Egypt. Then in 1947, the discovery of the Dead Sea Scrolls of early Jewish Gnostic writings occurred. Today, with many Christians wondering if the Second Coming of Christ is soon to happen, it may not be a coincidence that these secret writings have come to the surface after two thousand years of being hidden. Finally, after two thousand years, the secrets have been revealed.

Although modern theology normally takes the humanity of Jesus very seriously (sometimes to the neglect of his deity), those theologians who tend to drive a wedge between faith and history are confronted with the charge of opening the door to a new Docetism.

\section{References}

1 Norman L. Geisler, Baker encyclopedia of Christian apologetics. Baker reference library. Grand Rapids, Mich. ISBN-13: 978-0801021510

2 Roberts, J. Donaldson \& A. C. Coxe, The Ante-Nicene Fathers, Volume II: Fathers of the Second Century: Hermas, Tatian, Athenagoras, Theophilus, and Clement of Alexandria, Buffallo, NY ISBN 0802880886

3 Jack F. Kirsch, Simon Magus. The Catholic Encyclopedia. New York, ASIN: B005XENLOK

4 Arendzen, J. (2012) [1909]. «Docetae». The Catholic Encyclopedia 5. Robert Appleton Company. ASIN: B005XENLDS

5 Ferdinand Chrisitan Baur, Die christliche Gnosis oder die christliche Religions-Philisophiein ihrer geschichtlichen Entwicklung, Tübingen, ISBN-13: 978-1330891872

6 Michael Slusser, Docetism: a Historical Definition, The Second Century, 1981, 1:3 (1981:Fall)

7 Norbert Brox, 'Doketismus'eine Problemanzeige, Zeitschriftfuer Kirchengeschichte. 1984, ZKG 95 1984, Vol 95

8 M. J. Erickson, Christian theology (2nd ed.). Grand Rapids, Mich.: Baker Book House, 1998, ISBN-13: 978-0801021824

9 Ekkehard Mühlenberg, Docetism in Fahlbusch, E., \&Bromiley, G. W., 2003, ISBN-10: 9004145958

10 Marvin Olasky, «Onward Gnostic Soldiers», World magazine, May 202006.

11 Brian A. Bain, Near Death Experiences and Gnostic Christianity: Parallels in Antiquity, M.A. Journal of Near-Death Studies spring 1999, Vol. 17 No. 3

12 T. Nicklas\&Th. J. Kraus, Das PetrusevangeliumalsTeilantikerLiteratur, Berlin W. De Gruyter, 2007 ISBN-10: 0199208158

13 Thomas Nelson, Lost Books of the Bible and the Forgotten Books of Eden, Paperback 2002 ISBN-13: 978-0529020611

14 Ron Cameron, The Other Gospels: Non-Canonical Gospel Texts, Paperback - March 1, 2001, ISBN-13: 978-0664244286

15 H. Koester, Synoptische Uberlieferungbei den apostolischenVätern, Berlin Akademie-Verlag, 1957, ISBN: 9780800620936

16 Rev. D. H. Stanton, The Journal of Theological Studies volume XXI Oxford, Clarendon press, 1920, Vol 1

17 Selection made from James M. Robinson, ed., The Nag Hammadi Library, revised edition. HarperCollins, San Francisco, 1990, ISBN-13: 978-0060669355

18 Anderson, Paul N. The Christology of the Fourth Gospel; Its Unity and Disunity in the Light of John 6 (3rd printing, with a new introduction and a set of outlines; Eugene: Cascade Books, 2010 ISBN-13: 978-1606086292 